20. GREBLER, L. (1953) New Housebuilding under FHA and VA Programs: The Role of Federal Credit Aids in Residential Construction. In National Bureau of Economic Research [Online] Available from: http://www.nber.org/chapters/c9295.pdf (Accessed August 2, 2017).

21. Housing Act of 1949, Summary of Provisions. [Online] Available from: https://bulk.resource.org/gao.gov/81-171/00002FD7.pdf (Accessed August 2, 2017).

22. Servicemen's Readjustment Act (G.I. Bill) [Online] Available from: http://www.nolo.com/legal-encyclopedia/content/gi-bill-act.html (Accessed August 2, 2017).

23. Fair Labor Standards Act Amendments of 1949 [Online] Available from: https://fraser.stlouisfed.org/docs/historical/eccles/030_09_0002.pdf (Accessed August 2, 2017).

24. DEVANEY, J. F. (1994). Tracking the American dream: 50 years of housing history from the Census Bureau: 1940 to 1990 Current housing reports [Online] Available from: https://www.huduser.gov/portal//Publications/pdf/HUD-7775.pdf (Accessed August 2, 2017).

25. HOBBS, F., STOOPS, N. (2002) Demographic Trends in the 20th Century Census 2000 Special Reports [Online] Available from: https://www.census.gov/prod/2002pubs/censr-4.pdf (Accessed August 2, 2017).

Mariia Kravchenko, Ph.D. student

Taras Shevchenko National University of Kyiv, Kyiv

\title{
THE POLICY OF HARRY TRUMAN'S ADMINISTRATIONS ON SOLVING THE HOUSING PROBLEM IN THE USA IN 1945-1952
}

The article provides a detailed analysis of the policy of Harry Truman's Administrations on solving the housing problem in the USA in 1945-1952. The preconditions and causes of the emergence of a deep housing problem in the USA at the end of the World War II has been determined, the scale thereof has been highlighted. The ways to overcome the housing crisis, that were used by Harry Truman's Administrations in 1945-1952, namely a combination of government policy aimed at supporting the financial capability of Americans to buy or rent dwellings in housing programs of Federal Housing Administration and GI Bill, and policy aimed on public housing construction, have been analyzed.

Following on from the statistical sources, the results and consequences of the policy of Harry Truman's Administrations on solving the housing problem in the USA in 1945-1952 have been revealed and evaluated. The author claims that tendencies in the development of American housing that had emerged during Harry Truman presidency in the process of solving the housing problem in the USA were influencing the modern housing of the USA as well.

Key words: housing problem, public housing construction, Truman, the USA.

\section{УДК 930.25(73):94(73)"1953/2000"}

http://doi.org/10.17721/2521-1706.2017.03.164-180
Larysa Levchenko, doctor of historical sciences,

Petro Mohyla Black Sea National University, Mykolaiv (Ukraine)

\section{ROBERT WARNER AND HIS FIGHT FOR INDEPENDENCE OF ARCHIVES}

\begin{abstract}
This article is dedicated to the life and work of the 6th Archivist of the U.S.A. R. M. Warner, his struggle for the independence of the National Archives of the USA from the United States General Services Administration, the events of XXI International Conference of the
\end{abstract}


Round Table on Archives, CITRA, (Kuala Lumpur, Malaysia), that was held in a complex international setting during the Lebanon War in 1982. Defending the State of Israel's right to participate in the conference, $R . M$. Warner proved that the International Council on Archives is a professional organization of archivists around the world and cannot be subjected to political influence. A leading role in the personality of the head of the Archives is played by vocational education, which allows them to understand the essence of things, to experience all the facets of the problems of his profession and the field, which they manage. Gained experience is also very important, not only in the professional area, but also in the area of historical and archival science. Of course, the leader must possess personal communication skills and a certain charisma. The most important criterion of the head of the Archives is their non-participation in political parties and radical religious movements. Robert Warner met all these requirements. Not many would dare to risk their careers and confront the powers that be in upholding the principle of "archives out of politics». The author also focuses on the key figures of the described events - the archivists of Israel, the Soviet Union and Malaysia.

Key words: Robert Warner, US Archivist, National Archives and Record Administration.

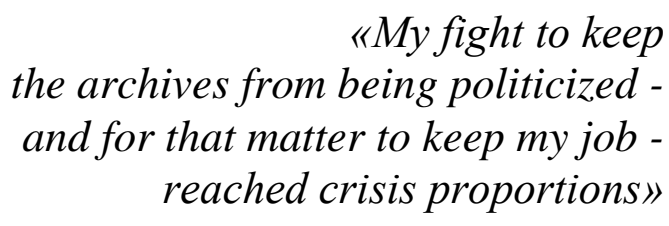

R.M.Warner, 6th Archivist of the USA

The debate on the place and role of archives in society, on the leading role of archives in shaping the politics of memory, on the influence of politics, ideology and religion on the archives, dependency of the archives on the authorities, archives' powers and responsibilities in the community has been continuing for many decades. Archivists have always upheld the principle of «archives out of politics», first of all, declaring their mission as professionals, whose main goal is to preserve the memory of mankind and transfer knowledge to future generations. Theoretical developments of various aspects of this area belong to a number of scientists, including a Ukrainian Vadim Modzalevsky [1], a Briton Hilary Jenkinson [2], a Jewish philosopher Jacques Derrida [3], Americans T. R. Schellenberg [4], R. C. Jimerson [5], Richard J. Cox [6], Canadians Terry Cook [7], Rodney G. S. Carter [8], Terry Eastwood [9], an Archivist of South Africa Verne Harris [10], an archivist of the Netherlands Eric Ketelaar [11], and a team of scientists from the UK, under the editorship of which a collection of essays «Political Pressure and the Archival Record» [12], containing the speeches of the participants of an international Conference on the increasing politicization of archives and records worldwide, was published in 2003 in School of History, University of Liverpool (Trudy Peterson, Tom Blanton (the USA); Friedrich Kahlenberg (Germany); Chris Hurley (New Zealand); Verne Harris (South Africa), and others) on topics: the use of records as an instrument of government, the destruction of records as a political act, the effects of corruption or ideology on records, secrecy and accountability, the nature and use of records resulting from repressive politics, and related issues of the archival profession. However different the opinions of the authors are, they are unanimous on the major issue: only if the archives are independent from the control of the authorities, the impact of policies, politicians and their party's interests, the «professional myth of impartiality, neutrality 
and objectivity» can be truly realized, and hence, records complexes, that objectively reflect the past and present in the future, can be formed.

However, the theory is not that easy to apply to real life and the works of these authors can be attributed to even a higher category, Archival Philosophy. Archives, in majority, are government agencies that function on the basis of state laws and are financed from the state budget, and in some countries, archivists belong to the category of public servants. Therefore, archivists defending their professional opinions often risk their careers, workplaces, financial well-beings, physical and mental health, if not lives. A huge contribution to the struggle for independence of the archives from politics was made by the 6th Archivist of the United States Robert M. Warner. In the complex political situation in the early 1980s, both within the U.S. and internationally, Warner managed to win the battle for the freedom of the archives from politics. Robert M. Warner described his «adventures» on «the field of battle» in two papers: «Diary of a Dream: A History of the National Archives Independence Movement, 1980-1985» and «International Archival Adventures: A Reminiscence» [13]. In the USA R. M. Warner was written about by his colleague and co-author, a professor in the School of Information and a professor in the Department of History University of Michigan; Francis X. Blouin [14], who inherited the post of director of the Historical Collections / Bentley Historical Library after Warner, as well as the Librarian and Archivist of Canada Ian E. Wilson [15]. Ian E. Wilson said about «Diary of a Dream» that this personal «diary of an archival leader is a rare document, providing a wealth of insight and experience for other public administrators, in and out of archives» and «a heroic tale» about an archival war, full of «battles and skirmishes, strategies and attacks, alarms, battle stations, spies, and even the occasional traitor». Battle took place in the corridors and offices of official Washington, and weapons were power, influence of the officials, threats, rumors. A period between August and December 1983 was the worst in «this heated conflict». It was the period of «Reign of Terror», marked by personal tragedy and «casualties» (during this period senior managers of the National Archives were fired and media speculated on the resignation of Warner himself). This rather frank and direct book is worth studying and understanding, according to Wilson. In this context, R. M. Warner, as a man and the head of the Archives, who managed to turn theoretical ideas into reality, deserves individual attention.

The author focuses her attention on the fate and professional work of a distinguished American scholar, historian, archivist R. M. Warner and complex twists and turns in which he had to defend the professional status of the National Archives of the United States and the International Council on Archives. Parallel to the main storyline the author will focus on various key figures of the events.

By the time Warner became the archivist of the United States, he already had a wealth of experience under his belt and was a respected researcher and practitioner among archivists and historians.

Robert Mark Warner was born on the $28^{\text {th }}$ of June, 1927 in Montrose, Colorado. He was the son of Mark Thomas, who was a Presbyterian minister, and Bertha Margaret (Rich) Warner. In 1949, he graduated from Muskingum College, a Presbyterian school in Ohio, where he studied history. In 1950-1952 Warner served in the US Army, in Germany first and later participated in the Korean War (1950-1953). After returning from service in the army Warner continued his education in the University of Michigan, Ann Arbor, where in 1953 he received an MA and in 1958 a $\mathrm{PhD}$ in history. His 
scientific interest at the time was focused on "recent" history (then defined as 1876 to the 1950s). While still a student in college Warner met Eleanor Jane Bullock, whom he married in 1954. According to Francis Blouin, Warner's wife has always played a major role in his career [16].

After receiving his doctorate Warner taught history at the University of Michigan. His acquaintance with the archives began during his college days when for his first research he used documents from the University of Michigan's Michigan Historical Collections (MHC). Warner later became a research assistant, and was the director of the MHC from 1966 to 1980. The library received the name of the Bentley Historical Library. Back in 1963 the library took records of Congressman Gerald R. Ford, who later became the President of the United States, for storage. When the question of admission of the records collected during Ford's presidency (1974-1977) arose, Warner suggested creating two separate structures: an archive (presidential library) and a museum. Ford Presidential Library was built in Ann Arbor and integrated into the academic programs of the university, and the museum was established in Grand Rapids. Warner later became a secretary of the Gerald R. Ford Foundation. In 1974, Warner was invited by the Dean Russell Bidlack to teach a course on archives in the School of Library Science, University of Michigan [17].

While working in the MHC Warner began to actively cooperate with the Society of American Archivists (SAA) and International Council on Archives (ICA). In SAA, he worked on the Council (1967-1971), as the Secretary (1971-1972), the Executive Director (1973-1974), the Vice President and the President (1976-1977). Warner came to the SAA in the early 1960s, which was a difficult period for the organization. It was a small company that did not have enough money and resources had suffered from bureaucracy. To change the situation in the SAA «the Committee on the Seventies», which recommended the establishment of a permanent office SAA and employment of an executive director, was founded. Warner, as the Secretary of the Company at the time, proposed to establish the SAA office in the graduate school building of the University of Michigan, which also housed the Michigan Historical Collections. He insisted on hiring a paid administrative assistant. This enabled the Company to strengthen its activities, and it was the first step in turning the SAA into an independent professional organization. In 1972 in a conflict situation between the SAA, the American Historical Association (AHA) and the Organization of American Historians (OAH), Warner defended SAA's right to full participation in the Joint SAA-OAH-AHA Committee on Historians and Archivists. Warner felt that this Committee should represent the interests of the SAA archives as sources for historical research. Committee later played an important role in the campaign for the independence of the National Archives. R. M. Warner believed that the profession of an archivist has a unique identity, its own distinctive features, methodological approaches that require special training. He emphasized the importance of professional literature, encouraged his colleagues to participate in the professional movements and organizations. In 1980 President Jimmy Carter (1977-1981) appointed Warner the 6th Archivist of the United States [18].

1982 was a challenging one in world politics: the world was on the brink of World War III. In 1970, Palestinian Liberation Organization (PLO) was banished from Jordan to Lebanon. The status of Palestinian refugees in Lebanon was determined by the Cairo Agreement on the $3^{\text {rd }}$ of November, 1969, signed with the support of the League of Arab States. However, P. L. O. usurped power in South Lebanon and turned it into a base for 
regular attacks against Israel. P. L. O. Militants were joined by volunteers from Iraq, Libya and South Yemen. Syria, which was supplied with military equipment and specialists by the Soviet Union, was actively helping P. L. O. The United States actively assisted Israel with weapons and army specialists [19].

As a result of P. L. O. actions and retaliatory attacks of the Israeli army on the eve of 1982 a number of civilians were lost. After the assassination of an Israeli diplomat Yakov Bar Simantov in Paris and an assassination attempt of the Israeli ambassador Shlomo Argov in London, on the $5^{\text {th }}$ of June, 1982 Israel made a decision to invade Lebanon to eliminate the P. L. O. The Lebanon war of 1982 began [20]. In fact, hostilities come to an end by September 1982. On the $18^{\text {th }}$ of August, 1982 a USbrokered agreement was signed, according to which the P. L. O. began evacuating to other Arab countries, and Israel made a commitment not to move deeper into Beirut. However, a truce was thwarted by the assassination of the newly elected Lebanese President Bashir Gemayel. Israeli forces occupied Beirut. On the $16^{\text {th }}$ and $17^{\text {th }}$ of September Lebanese Christian Phalangists arranged a sweep of P. L. O. fighters in Sabra and Shatila camps, that turned into full-scale massacre of the Palestinians. The massacre led to a resurgence of anti-Israel sentiment in the world and the anti-war sentiment in Israel. A final peace agreement between Lebanon and Israel was signed Gemayel's brother, Amine, in May 1983, but only in the year 2000 the Israeli army was able to finally leave Lebanon. Soviet forces left the territory of the Syrian Arab Republic in July 1984.

In this difficult international situation in the Malaysian capital of Kuala Lumpur from the $29^{\text {th }}$ of November till the $4^{\text {th }}$ of December, 1982 a peace conference was held by the keepers of history, archivists. It was organized by the International Council on Archives. The twenty-first International Conference of the Round Table on Archives was attended by archivists from 38 countries: Australia, England, Argentina, Belgium, Ivory Coast, Brunei, Guyana, Gambia, Zimbabwe, Indonesia, Spain, Italy, Canada, Congo, Korea, Luxembourg, Malaysia, Macau , Mozambique, the Netherlands, Pakistan, Papua New Guinea, Portugal, Rwanda, Saudi Arabia, Senegal, Singapore, Tunisia, the Philippines, France, the Federal Republic of Germany, Switzerland, Sweden, Sri Lanka, Japan, as well as Lebanon, the U.S. and the USSR. The USSR delegation was headed by the Chief of Archives Administration of the Ukrainian Soviet Socialist Republic, Alexander Mityukov (Kiev, Ukraine) [21]. The 6th Archivist Robert Warner (Washington, USA) participated in the conference as a representative of the United States. According to A. Mityukov, the conference considered questions important for all archives in all countries: the policies of national and state archives in the area of microfilming in order to create security copies, the publication of historical sources, and the creation of access copy funds used to protect original archival documents. They also discussed the development of standards for microfilming programs of all kinds. During the conference ICA planned to adopt the Rules of Procedure of the International Round Table Conference on Archives. State Archival Service of Malaysia intended to invite participants to the opening of the new building of the National Archives [22].

During that time such well-known professional archivists as Aryeh Arad (Israel State Archives staff member, who repeatedly spoke during the International Congress on Archives), Daniel Cohen (1921-1989, the director of Central Archives for the History of the Jewish People at the Hebrew University in Jerusalem), Yitzhak Arad (1926 -?, Itzhak Rudnicki, the director of Yad Vashem Archives in 1972-1993, who fought in the ranks of 
Soviet partisans in World War II, a historian and author of many works on the Holocaust) worked in the archives of Israel.

The state archives of Israel in those years were headed by the famous Israeli historian Professor Paul Avraham Alsberg (1919-2006). He was a distinguished researcher and practitioner among archivists. He was born in Wuppertal, Germany in 1919. In 1938, Alsberg was arrested by the Nazis and spent several months in Buchenwald. In January 1939 he managed to immigrate to Palestine. After graduating from the History and Romance Philology at the Hebrew University, Paul A. Alsberg headed the institutional archives section of the Central Zionist Archives in Jerusalem since 1949. In 1957 he defended his thesis and received a PhD. Paul A. Alsberg's talent was noticed by Dr. Alex Bein, Israel's first State Archivist at the time. He appointed Alsberg the director of the State Archives. In 1956 Alsberg began teaching courses on archives at the Hebrew University. He has devoted more than 30 years to teaching, becoming a professor at the Hebrew University in 1985. In 1971, following the retirement of Dr. Alex Bein, Alsberg was appointed the Second State Archivist of Israel. He played a key role in the archival system in Israel until his retirement in 1990. Alsberg made significant contributions to the international archival community: He served on several ICA Committees and on the Executive Committee (1972-1974), and became an honorary member of ICA in 1988. Alsberg's scientific interests included issues of the impact of archival theory on professional practice and the administrative history of Palestine during the British mandate. In the field of archival science Alsberg developed the theory of records appraisal, the criteria of value, mainly based by the teachings of a prominent British archivist Hilary Jenkinson and the famous American theorist and practitioner of archival science Theodore R. Schellenberg. Alsberg developed rules of records selection for permanent storage used in the Israel State Archives. The Guide to the Israel State Archives was published under his editorship. He maintained close connection with the archivists around the world [23].

In 1982 the Malaysian government allowed neither Paul A. Alsberg, nor anyone else from the Israeli archivists to enter the country to attend the conference of the International Council on Archives. Since 1969 Malaysia has been a member of the Organization of Islamic Cooperation, set up to ensure Islamic solidarity in the social, economic and political spheres, as well as to support the Palestinian Liberation Organization. Since 1981 the Prime Minister (July 16 ${ }^{\text {th }}, 1981$ - October $31^{\text {st }}, 2003$ ) and president of the United Malays National Organization (UMNO) Mahathir Mohamad, who, along with the economic prosperity of the country, pursued the interests of the expansion of Islam and Malay nationalism gained a significant influence in Malaysia [24].

The Director of the National Archives of Malaysia in those years was Zakiah Hanum Nor (1977-1995). She was a professional archivist, art historian and progressive public figure (from 1972 - President of the Muslim Women's Action Society (Pertiwi). Zakiah Hanum Nor came to work in the National Archives immediately after graduation from the University of Malaya (1961) and a year-long internship in the National Archives of India (New Delhi), where she obtained a Diploma in Archives Administration (1962). In 1977 she became the head of the archives and turned it into the most professional and technically advanced one in all Southeast Asia. In 1980-1984 she worked as Executive Council Member International Council on Archives in Paris, as well as the chairman of the Commonwealth Archivist and Record Managers Association in Malaysia [25]. 
Malaysian archivists did not support the decision of their government. Warner writes: «Our overall relations were good with Malaysia, and I pointed out that Zakiah Hanum Nor, our host and the archivist of Malaysia, was not sympathetic to her government's position on this issue, and that it would be a shame to ruin her meeting» [26].

The visit of the 6th Archivist of the USA, Robert Warner to Malaysia in war circumstances was threatened too. Firstly, Warner was already known for his extraordinary views, sometimes going against the official policy of Washington. Warner's friendship with Soviet archivists has ensued during the VII International Congress on Archives, held in Moscow on 22-25 August, 1972. Warner and his wife then attended not only Moscow but also Armenia and Georgia. He fondly recalled the friendly connections, established with his colleagues from the Soviet Union. In 1980, when the Soviets invaded Afghanistan, and the USA boycotted the Moscow Olympics, Warner suggested to hold on presentation in Washington of a collection of documents «Russia and the United States. Establishing a relationship. 1765-1815», on which archivists from both countries had been working for four previous years, despite the complex political relations during the Cold War (1945-1991). The collection includes more than 1,000 documents from the U.S. and Soviet archives. The U.S. State Department refused to conduct a presentation in Washington. The collection was presented in London during the IX International Congress on Archives (15-19 September 1980, London, UK). The executive director of the International Council on Archives Charles Kecskemety helped significantly in the organization of the presentation. The American side was represented R. M. Warner, James O'Neill, Bert Rhoads, and Charles M. Dollar. The Soviet side consisted of A. M. Pegov, Deputy Head of the Main Archival Administration under the Council of Ministers of the USSR, A. G. Mityukov, Head of the Archives Department of the Ukrainian SSR, M. I. Avtokratova, director of the Central State Archives of Ancient Acts of the USSR, A. A. Menalashvili, Head of the Archives Department of the Georgian SSR, B. R. Ramazanova, Head of the Archives Department of the Kazakh SSR, and other delegates. During this Congress the representative of the Soviet delegation S. L. Tihvinsky, Head of History and Diplomatic Directorate of the Ministry of Foreign Affairs, introduced a draft resolution on the commitment of ICA member countries to principles of the Final Act of the Conference on Security and Cooperation in Europe (Helsinki, 1975), the principles of development and advancing detente, disarmament and peace. The adopted resolution established that members of the ICA undertake to make every effort to prevent the use of archives to promote militarism, racial hatred and be used as ideological weapons of the «Cold War». They also ventured to promote archival records in order to strengthen the trust and cooperation between peoples in all fields of human civilization [27].

In 1981, Warner had to overcome significant obstacles in order to send a delegation of American Archivists to the XX International Conference of the Round Table archives in Oslo (Norway, 3-7 September, 1981). He even refused to go himself just for someone to be able to. In Oslo at an informal reception with the traditional vodka, organized by the head of the Main Archival Administration under the Council of Ministers of the USSR Filip Dolgikh, American and Soviet archivists «drank toasts to continued friendships between our institutions, stopping only when the bottle was empty». And while new projects were not possible before the Soviet «glasnost» period, «the pleasant evening we spent illustrates that warm professional contact can transcend the political problems of the time», R. M. Warner wrote in his memoirs. In 1982 R. M. Warner accepted a 
delegation of archivists from the People's Republic of China at the National Archives in Washington, and was planning to visit China along with his colleagues. After that, the head of General Services Administration Gerald P. Carmen accused Warner and the staff of US National Archives in the propensity to communist ideas [28].

Secondly, back in 1949 on the recommendation of the first Hoover Commission (1947-1949) «Federal Property and Administrative Services Act» (PL 152) was adopted. It created the General Services Administration (GSA), a service that had to help manage and support the basic functioning of federal agencies. It supplied products and communications for US government offices, provided transportation and office space to federal employees, and developed government-wide cost-minimizing policies. In December 1949 National Archives and Records Administration (NARA) was subjected to this service. NARA not only changed its name to the National Archives and Records Service (NARS), but also lost its status as an independent agency of the executive branch of the government. On one hand, the authority of NARS was enhanced, because of the control functions of records management programs in the federal departments [29]. On the other hand, all the rights and powers of the Archivist of the USA, obtained during the foundation of the Archives by President Franklin D. Roosevelt (1933-1945) in 1934, according to the "An Act to establish a National Archives of the United States Government, and for other purposes» (1934, S. 3681, HR 8910), were transferred to the chief of General Services Administration, so the Archivist the United States could no longer make his own decisions, manage the budget, establish a personnel policy or plan archival activities. It also reflected on international activities. The conflict between the GSA and NARS escalated dramatically over time. When NARA was subject to GSA, the post of the Archivist of the United States was held by Wayne Clayton Grover (June 2, 1948 - November 6, 1965). After becoming the President of the United States, Dwight D. Eisenhower (1953-1961) was planning to make the position of the Archivist of the United States a political one and replace Grover with a politician. However, both archivists and historians in the United States opposed this initiative. It was the first victory of American archivists, who not only protected their head against unfair dismissal and proved that a new President does not guarantee replacement of qualified professional archivists, but also took the first step towards the professionalization of the archival service as a whole. Following this instance, American archivists took significant steps to improve archival education and set standards of their profession. A discussion about the certification of archivists, which ended in the late 1980s with the creation of «Academy of Certified Archivists» [30], was launched. Grover was a successful leader, but in 1965, the conflict between NARS and GSA regarding budget cuts forced him to leave his post. Before leaving Grover wrote a letter to President Lyndon B. Johnson (1963-1969) requesting reestablishment of the National Archives as an independent agency [31].

Warner began working at the National Archives of the United States ready to develop collaboration with the head of GSA. Soon, however, the conflict between the GSA and NARS reached its highest point. President Ronald Reagan (1981-1989) appointed Gerald P. Carmen (1930-?), who had extremely conservative views, as the head of the GSA. Already in December 1981 the Archives were swept by the first round of layoffs. In mid-October 1983 Carmen, despite resistance from Warner, replaced senior archives managers in the U.S. National Archives. Warner later wrote in his «Diary of a Dream: A History of the National Archives Independence Movement», that Carmen decided «to make life so miserable for me that I will resign, or so totally isolate me that I 
will have no effectiveness» [32]. It became clear to Warner that the Archives can no longer remain a hostage of the GSA. In 1982-1983 Warner was actively seeking allies among archivists, historians and politicians of Capitol Hill to campaign liberation of the Archives. A group of six like-minded people who first met every two weeks, then every week, then every two days, and finally daily formed in the Archives. This group was headed by Warner, but because he had to report to the head of GSA, he and his comrades met secretly. These were informal sessions at the office table, where information from various sources was discussed, strategy was planned, decisions were made regarding contacts with members of Congress, the press, etc. Archivists from the Lyndon B. Johnson and the Gerald R. Ford presidential libraries helped Warner's group to intensify contacts with members of Congress. Outside the Archives the executive director the American Historical Association (AHA) Samuel Gammon, head the National Coordinating Committee for the Promotion of History (NCC) Page Putnam Miller, the National Coalition to Save our Documentary Heritage, the Organization of American Historians, the Society of American Archivists, the American Library Association, the National Genealogical Association all took Warner's side. A key role in advancing the interests of the Archives and the new archival legislation in the Congress and the White House was played by representatives Glenn English of Oklahoma, Jack Brooks of Texas, Frank Horton of New York, senators Thomas Eagleton of Missouri, Charles Mathias of Maryland, Mark Hatfield of Oregon. American archivists nicknamed this period the Archival Revolutionary War, which was conducted in the corridors of power. Finally, on 3-4 October 1984 the U.S. Congress passed, and October 19, 1984 President Ronald Reagan signed a bill, liberating the National Archives from the GSA starting on April 1, 1985. Warner wrote about it: «The good guys finally won» [33].

In 1982, Warner was on a business trip to Tokyo (Japan), where from he was to travel to Malaysia. While in Tokyo, he learned that the Malaysian government did not allow the Israeli delegate to come to Kuala Lumpur for the conference. He immediately got in touch with a representative of the American Embassy, Francis J. Tatu, who reported that the US State Department expressed their protest on the case to the Malaysian foreign ministry. The American stance was to support Israel's right to participate in this nonpolitical, professional meeting. The Malaysian government was adamant though, and some delegates from Muslim countries even insisted on completely prohibiting Israel to participate in the International Council of Archives. The U.S. embassy supported the stand of its government in the Israeli issue, but at the same time did not want to raise the hype around this problem. Warner, discussing the issue with U.S. Ambassador in Malaysia, Ronald D. Palmer, suggested making a statement, which would condemn the politicization of international professional meetings, releasing it prior to the conference and winning the support of its members. Warner knew that any decision taken by the United States on this issue would make a huge impact on every delegate and the fate of the Round Table as a whole, since the United States initiated the creation of ICA [34]. Delegates' opinions were divided: representatives of the Netherlands and Sweden pushed for «a strong letter both deploring the banning of the Israeli delegate and refusing to attend», while Great Britain wanted to make a milder statement. For the next two days Warner was writing his statement and coordinating its text with the U.S. Embassy in Malaysia and US State Department in Washington, DC. At the same time he spoke to the delegates from different countries, trying to convince them of the importance of such a statement. Delegates from Germany, France, Canada, the UK, Belgium and 
Sweden agreed to support Warner. At the closing session of the conference, after the announcement of a more radical statement of a delegate from the Netherlands, President of the ICA A. W. Mabbs gave the floor to Warner, who delivered this speech: «On behalf of the United States Government and speaking personally, I want to associate myself with the position of our colleague from The Netherlands. This meeting has dealt with professional and technical problems of archives from around the world in a friendly and constructive manner, greatly facilitated by the National Archives of Malaysia, our host. But there has been a cloud over this meeting which has now been brought before us by our Dutch colleague. A member in good standing of the ICA, entitled to attend this Round Table, was not permitted to share in these constructive deliberations because of political considerations beyond the control of the National Archives of Malaysia. The introduction of political consideration into this professional meeting is saddening and regrettable to all concerned with the international development of the archival profession. But we can learn from this experience to ensure that never again will the Round Table Conference be placed in this position. We must ensure that any host nation will guarantee admission of all members of the Round Table. In this period when the world faces many problems, we have a special need to ensure that organizations such as the Round Table, which are concerned with technical, professional, and cultural topics, are allowed to flourish and function in a climate of high-level professionalism, free from the burden of political constraints» [35]. Thus, the crisis situation at the conference was resolved rather amicably. Warner recalled that «The Russian representative also came by to say an especially friendly goodbye». With this statement, Warner set a precedent, so that in the future such professional meetings would not be subjected to political pressure and no international conflicts could affect archivists' professional activities, designed to take care of the documentary heritage of humanity.

Other important activities conducted by Warner at the post of the Archivist of the United States are the execution of twenty year long plan to improve the safety of records (1984), the creation of a technology assessment division, the completion of the appraisal and retention plan for FBI records (1981), controversy over the Richard Nixon Presidential papers, the founding of the Carter Library (Atlanta, Georgia, construction began in October 1984, the library opened Oct. 1, 1986) and planning of the Ronald Reagan Library (Simi Valley, California, planning began in 1984, the library opened on 4 November 1991). In 1985, Warner participated in the X International Congress on Archives in Bonn (17-21 September 1985, the Federal Republic of Germany), in which he was elected a member of the Executive Committee and the ICA Committee of archival development. In this Congress, a new round of friendly relations with the archivists of the USSR began with a meeting with Feodor M. Vaganov, chief of the Main Archival Administration under the Council of Ministers of the USSR.

At the end of 1984 Warner decided to leave the post of the Archivist of the United States and return to the University of Michigan to take the post of the Dean of the School of Information and Library Studies (SILS). He worked in the Archives till April 1985. From 1988 to 1991 he also served as the acting director of the University of Michigan Library. Warner left the post of dean in 1992, stepping down to retire. During this time he worked closely with the Society of American Archivists, the American Historical Association and the American Library Association.

Warner continued to work actively in the ICA. In 1986, he visited the USSR again during the sessions of the ICA Committee on Archival Development Meeting (Leningrad 
(St. Petersburg), September 8, 1986) and the ICA Executive Committee Meeting (Leningrad, 9-12 September 1986). He recalled that «the Russians were extremely cordial to me personally». The reason for the Soviet archivists' goodwill to Warner was his active assistance in signing the Agreement on cooperation between the U.S. and Soviet archivists. The idea of this collaboration came up at the $\mathrm{X}$ International Congress on Archives in Bonn. On February 19, 1987 in Washington, DC, the Agreement on Cooperation was signed by the Main Archive Department under the Council of Ministers of the USSR and the American Council of Learned Societies and the Protocol of the Joint Soviet-American Commission on Archival Cooperation for 1987-1988. This enabled a Soviet-American Symposium on Accounting, finding aids to the documents in the introduction of automated technologies and the computerization of records to be held on the 15-18 May, 1990 in Moscow [36]. Warner had the most wonderful memories about his visit to Leningrad. He wrote with admiration about the Hermitage museum, a boat trip to Petrovorts, the very extensive restoration project of Peter the Great's summer palace [37].

Warner wrote a number of works in the field of archives and American history. Among them are the articles «The Status of College and University Archives», «International Council on Archives and UNESCO Meetings, September and November, 1986», «The Role of the Secular Institution in Collecting Church Records», «Documenting the Great Migrations and a Century of Ethnicity in America», «The Prologue Is Past», «American Archivists and Their Society: A Composite View», «Archival Training in the United States and Canada» and books «Modern Manuscript Library», «Inside the White House: The presidential library system», «Point of intersection: The university library and the pluralistic campus community», «Guide to Manuscripts In the Michigan Historical Collections of the University of Michigan» and others.

Warner's service to the National Archives of the USA was appreciated by his colleagues. In 2005, to celebrate the 20th anniversary of the independence of the National Archives of the United States the Research Center for former Archivist of the United States Robert M. Warner was opened as a part of the Archives in Washington, DC.

I would like to finish my article on Robert Warner with some arguments about how important the merits of a leader, who heads the archival sector, are. In 1934, when the question of the appointment of the $1^{\text {st }}$ Archivist of the United States was pending, the famous American historian, founding father of the National Archives, John Franklin Jameson (1859-1937) was very much afraid that the archives will be headed by a political appointee. Jameson said on this occasion: «Whom the President would think of, I have no idea, but he is enough of a historical scholar to make me think that, in canvassing qualifications, he will not leave historical-mindedness out of account. Another prime qualification would be ability to get along with the departments, with some of whom it would be easy to have a succession of rows; yet the archivist must have a stiff backbone and power enough to fight well for his own views» [38]. In 1934, Professor of History University of North Carolina, Dr. Robert D. W. Connor was appointed as the First Archivist of the United States. And when the press was gloating that Connor was more like a «very conservative country schoolmaster» or «a communist», he said in response: «No, dear children, an archivist is not a radical. He is one who preserves historical documents» [39]. A leading role in the personality of the head of the Archives is played by vocational education, which allows them to understand the essence of things, 
to experience all the facets of the problems of his profession and the field, which they manage. Gained experience is also very important, not only in the professional area, but also in the area of historical and archival science. Of course, the leader must possess personal communication skills and a certain charisma. The most important criterion of the head of the Archives is their non-participation in political parties and radical religious movements. Robert Warner met all these requirements. Not many would dare to risk their careers and confront the powers that be in upholding the principle of «archives out of politics». Warner was an active supporter of the professional mission of archives and archivists, which consists in preserving the memory of mankind and the transfer of knowledge to future generations. In defending the independence of the National Archives of the United States and the right of Israeli archivists to participate in the International Round Table Conference on Archives, he demonstrated an example of a leader and an archivist, worthy of respect and emulation by archivists of all countries.

\section{Sources and literature}

1. Vadim Modzalevsky declared the principles of political and party indifference of archives as well as their orientation on national idea in 1918-1924. For more on his activities: Матяш Ірина. Архівознавство: методологічні засади та історія розвитку / Ірина Матяш. - К.: Видавн. дім «КиєвоМогилянська академія», 2012. - Р. 350-352.

2. Jenkinson H. A Manual of Archive Administration including the problems of War Archives and Archive Making / H.Jenkinson. - Oxford: Clarendon Press, 1922. - P. 1-22, 163-165.

3. Derrida J. Archive Fever: A Freudian Impression / J.Derrida. - Chicago: University of Chicago Press, 1998. -113 p.

4. Schellenberg T. R. Modern Archives: Principles and Techniques / T. R. Schellenberg. Chicago: University of Chicago Press, 1956. -247 p.; Schellenberg T. R. The Management of Archives / T. R. Schellenberg. - New York: Columbia University Press, 1965. - 383 p.

5. Jimerson R.C. Embracing the Power of Archives / R.C. Jimerson // American Archivist. - 2006, Spring/Summer. - Vol. 69, № 1. - P. 19-22; Jimerson R.C. Archives for All: Professional Responsibility and Social Justice / R.C. Jimerson // American Archivist. - 2007, Fall/Winter. - Vol. 70, № 2. - P. $252-$ 281.

6. Cox R.J. Secrecy, Archives, and the Archivist: A Review Essay (Sort Of) / R.J. Cox // American Archivist. - 2009, Spring/Summer. - Vol. 72, № 1. - P. 214-231.

7. Cook T., Schwartz J.M. Archives, Records, and Power: The Making of Modern Memory /T.Cook, J.M. Schwartz// Archival Science. - Kluwer Academic Publishers, 2002. - № 2. - P. 1-19.

8. Carter R. Of Things Said and Unsaid: Power, Archival Silences, and Power in Silence / R.Carter // Archivaria. - 2006, Spring. - Vol. 61. - P. 215-233.

9. Eastwood T. Reflections on the Goal of Archival Appraisal in Democratic Societies / T.Eastwood // Archivaria. - 2002, Fall. - Vol. 54. - P. 59-71.

10. Harris V. Archives and Justice: A South African Perspective. With a foreword by Terry Cook / V.Harris. - Chicago: Society of American Archivists, 2007. - 447 p.

11. Ketelaar E. Archival Temples, Archival Prisons: Modes of Power and Protection / E.Ketelaar // Archival Science. - Kluwer Academic Publishers, 2002. - № 2. - P. 221-238.

12. Political Pressure and the Archival Record. [/Edited by M.Procter, M.G. Cook, C.Williams]. Chicago: Society of American Archivists, 2005. - 345 p.

13. Warner R.M. Diary of a Dream: A History of the National Archives Independence Movement, 1980-1985 / R.Warner. - Metuchen, NJ. and London: The Scarecrow Press, 1995. - 211 p.; Warner R.M. International Archival Adventures: A Reminiscence / R.Warner // American Archivist. - 1992, Spring. Vol. 55, № 2. - P. 356-368.

14. Blouin F.X. The Two Dimensions of Professional Service: A Reflection on the Life of Robert M. Warner / F.X. Blouin // American Archivist. - 2007, Fall-Winter. - Vol. 70. № 2. - P.401-409; Blouin F.X. Remembering Robert M. Warner // Bentley Historical Library University of Michigan. 
[Electronic Resource] - Mode of Access: http://bentley.umich.edu/general/warner.php (Last Access: April 4, 2013) - Title from the Screen.

15. Wilson I.E. Diary of a Dream: A History of the National Archives Independence Movement, 1980-1985. Reviews / I. E. Wilson // American Archivist. - 1998, Spring. - Vol. 62. № 1. - P. 164-197.

16. Biography // Friedman L., Neal K. (1994), Monahan Z. (2005). Finding aid for Robert M. Warner Papers, 1958-1992. University Archives and Records Program Bentley Historical Library University of Michigan. [Electronic Resource] - Mode of Access: http://quod.lib.umich.edu/b/bhlead/umich-bhl-89405?rgn=main;view=text (last access: August 4, 2017) Title from the Screen; Blouin F.X. Remembering Robert M. Warner. Bentley Historical Library University of Michigan. [Electronic Resource] - Mode of Access: http://bentley.umich.edu/general/warner.php (Last Access: April 4, 2013) - Title from the Screen.

17. Blouin Francis X. Jr., Bellardo L. Robert Warner. American Historical Association. [Electronic Resource] - Mode of Access: http://www.historians.org/perspectives/issues/2007/0709/0709mem3.cfm (last access: August 4, 2017) - Title from the Screen

18. Blouin F.X. The Two Dimensions of Professional Service: A Reflection on the Life of Robert M. Warner / F.X. Blouin // American Archivist. - 2007, Fall-Winter. - Vol. 70, № 2. - P. 401-409.

19. Булат П. Ливанская война 1982 г. - «Мир Галилее». История одного мифа. Часть IV. Шесть дней [Электронный ресурс] - Режим доступа: https://www.researchgate.net/publication/279961015_Ob_istorii_odnogo_mifa_Cast_IV_Sest_dnej (Дата обращения: 4 Августа 2017) - Название с экрана; Ливанская война Электронная еврейская энциклопедия [Электронный ресурс] - Режим доступа: http://www.eleven.co.il/article/12442 (Дата обращения: 4 Августа 2017) - Название с экрана; Военная помощь СССР странам Ближнего и Среднего Востока. Участие контингента советских войск в арабо-израильских войнах (1956-1982 гг.) // Россия (СССР) в войнах второй половины XX века. - М.: Триада-Фарм, 2002. - С. $447-$ 482; Поборцев А. Бейрут-82: Неизвестная война Брежнева. Документальный фильм. NTV, 2009. [Электронный ресурс]. - Режим доступа: https://rutube.ru/video/bbf607bf3fe2b535ba9641ecaaebe4a9 (Дата обращения: 4 Августа 2017) - Название с экрана.

20. Martin G. The Routledge Atlas of the Arab-Israeli Conflict. $8^{\text {th }}$ Edition with thirty-two new maps. London and New York, 2005. - P. 100 (Terrorism inside Israel, 1975) 107 (Israel, the P.L.O., and the Lebanon, 1976-1978), 113 (The balance of forces in the Lebanon, 1981), 114 (Civilians killed and wounded in terrorist attacks, January 1980 - October 1982), 124 (The war in Lebanon, 6 June 1982 - 21 August 1982.

21. Центральний державний архів вищих органів влади та управління України [Central State Archives of Supreme Bodies of Power and Government of Ukraine]. - Ф. 14, оп. 2, спр. 3122, арк. 128 [Fond 14, inv. 2, file 3122, page 128].

22. Мітюков О. Г. XXI Міжнародна конференція Круглого Стола Архівів / О. Г. Мітюков // Архіви України. Науково-інформаційний бюлетень Головного архівного управління при Раді Міністрів Української РСР. - 1983, березень-квітень. - № 2 (178). - С. 17-24.

23. In Memoriam: Paul Alsberg. International Council on Archives [Electronic Resource] - Mode of Access: http://www.wien2004.ica.org/en/node/813 (last access: April 4, 2013] - Title from the Screen; Aloufi Z. Apprisal at the Municipal Archives in Israel / Z.Aloufi // Atlanti. - Trieste, 2008. Vol. 18. - P. 287-295; Guide to the archives in Israel. [/Ed. by P. A. Alsberg]. - Jerusalem: Israel Archives Association, 1973. - 257 p.; Alsberg P. The Israel State Archives as a source for the history of Palestine during the period of Ottoman rule / P.Alsberg // Studies on Palestine during the Ottoman Period / [Ed. by Moshe Ma'oz]. - Jerusalem: Magnes Press, 1975. - 582 p.; Alsberg P. The Israel State Archives / P.Alsberg // Archivaria. - 1978, Winter. - № 7. - P. 70-75; Alsberg P. The Israel State Archives. Guides to the archives in Israel. Vol. 1. / P.Alsberg. - Jerusalem: Israel Archives Association, 1991. $106 \mathrm{p}$.

24. Malaysia. Islam, Society and Politics / [Ed. by Hooker V., Othman N.]. - Singapore: Institute of Southeast Asian Studies, 2003. - 263 pp.; Ufen A. Malaysia. Mobilizing Political Islam: Indonesia and Malaysia Compared / A.Ufen // Commonwealth and Comparative Politics. - 2009, July. - Vol. 47, № 3. P. 308-333.

25. Datuk Zakiah Hanum Haji Abdul Hamid. Former ANM Director. National Archives of Malaysia [Electronic Resource] - Mode of Access: http://www.arkib.gov.my/en/datuk-zakiah-hanum- 
haji-abdul-hamid (Last Access: April 4, 2013) - Title from the Screen; Abishegan J. Datuk Zakiah Hanum // Sunday Style. New Sunday Times. - 1993, March 14. - P. 5.

26. Warner R.M. International Archival Adventures: A Reminiscence / R. Warner // American Archivist. - 1992, Spring. - Vol. 55, № 2. - P. 362.

27. Warner R.M. International Archival Adventures: A Reminiscence / R. Warner // American Archivist. - 1992, Spring. - Vol. 55, № 2. - P. 357-360; Мітюков О. Г. IX Міжнародна конференція круглого столу архівів / О. Г. Мітюков // Архіви України. Науково-інформаційний бюлетень Головного архівного управління при Раді Міністрів Української РСР. - 1980, листопад-грудень. № 6 (164). - C. 10-11.

28. Warner R.M. International Archival Adventures: A Reminiscence / R. Warner // American Archivist. - 1992, Spring. - Vol. 55, № 2. - P. 361-362.

29. Krauskopf R.W. The Hoover Commissions and Federal Recordkeeping / R. Krauskopf // American Archivist. - 1958, October. - Vol. 21, № 4. - P. 371-385; Angel H.E. Federal Records Management Since the Hoover Commission Report / H. Angel // American Archivist. - 1953, January. Vol. 16, № 1. - P. 13-26.

30. Byers J. Certification in America: The ACA Example. Academy of Certified Archivists [Electronic Resource] - Mode of Access: https://www.certifiedarchivists.org/about-us/historicalresources/certification-in-america-the-aca-example (Last Access: August 4, 2017) - Title from the Screen.

31. Bradsher G. Longest-Serving Archivist Wayne Grover Steered Agency during Critical Years / G. Bradsher // Prologue. - 2009, Winter. - Vol. 41, № 4 [Electronic Resource] - Mode of Access: http://www.archives.gov/publications/prologue/2009/winter/grover.html (Last Access: August 4, 2017) Title from the Screen.

32. Warner R.M. Diary of a Dream: A History of the National Archives Independence Movement, 1980-1985 / R. Warner. - Metuchen, NJ. and London: The Scarecrow Press, 1995. - P. 102.

33. Warner R.M. Secrecy and Salesmanship in the Struggle for NARA's Independence / R. Warner // Proloque. - 2005, Spring. - Vol. 37, № 1 [Electronic Resource] - Mode of Access: http://www.archives.gov/publications/prologue/2005/spring/archivist-warner.html (Last Access: August 4, 2017) - Title from the Screen; Archives Becomes Independent // Abbey Newsletter. - 1984, December. - Vol. 8, № 6 [Electronic Resource] - Mode of Access: http://cool.conservationus.org/byorg/abbey/an/an08/an08-6/an08-602.html (Last Access: August 4, 2017) - Title from the Screen.

34. International Council on Archives (ICA) was created during an organizational conference on the $9^{\text {th }}$ of June, 1948 in Paris. Charles Samaran (1879-1982), the General Director of the Archives of France, was elected as the first President of the ICA. The Second Archivist of the United States Solon J. Buck (1884-1962 and the world renowned British archivist and scholar, Deputy Keeper of the Public Records Sir. Hilary Jenkinson (1882-1961) were elected as vice-presidents of the ICA. The First International Congress on Archives was held in Paris on 21-26 August 1950. U.S. Archivist Solon J. Buck came up with the initiative of creating ICA. // Holmes W. Oliver. Toward an International Archives Program and Council, 1945-1950 / Oliver W. Holmes // American Archivist. - 1976, July. - Vol. 39, № 3. - P. 287-296; Buck J. Solon. The Archivist’s «One World». Presidential address, delivered at the tenth annual meeting of the Society of American Archivists, at Washington, October 24, 1946 / Solon J. Buck // American Archivists. - 1947, January. - Vol. 10, № 1. - P. 9-24; Norton Margaret C. The First International Congress of Archivists, Paris, France August 21-26, 1950 / Margaret C. Norton // American Archivist. - 1951, January. - Vol. 14, № 1. - P. 13-32.

35. Warner R.M. International Archival Adventures: A Reminiscence / R. Warner // American Archivist. - 1992, Spring. - Vol. 55, № 2. - P. 363.

36. Warner R.M. International Archival Adventures: A Reminiscence / R. Warner // American Archivist. - 1992, Spring. - Vol. 55, № 2. - P. 356-368; Советские архивисты в США // Советские архивы. Научно-теоретический и научно-практический журнал. - М.: Главное архивное управление при Совете Министров СССР, 1987. - № 3. - С. 91-92; Архивисты из США в СССР // Советские архивы. Научно-теоретический и научно-практический журнал. - М.: Главное архивное управление при Совете Министров СССР, 1988. - № 1. - С. 104-105.

37. International Council on Archives and UNESCO Meetings, September and November, 1986 // American Archivist. - 1987, Spring. - Vol. 50, № 2. - P. 262-264. 
38. Shelley F. The Interest of J.Franklin Jameson in the National Archives: 1908-1934 / F.Shelley // American Archivist. - 1949, April. - Vol. 12, № 2. - P. 129.

39. Connor R. D. W. Adventures of an amateur archivist / R. D. W. Connor // American Archivist. - Vol. 6. - № 1. - January, 1943. - P. 7.

\section{References}

1. MATYASH, IRYNA (2012). Arxivoznavstvo: metodolohichni zasady ta istoriya rozvytku. Kyiv: Vydavn. dim «Kyyevo-Mohylyanska akademiya».

2. JENKINSON, H. (1922) A Manual of Archive Administration including the problems of War Archives and Archive Making. Oxford: Clarendon Press, P. 1-22, 163-165.

3. DERRIDA, J. (1998) Archive Fever: A Freudian Impression. Chicago: University of Chicago Press.

4. SCHELLENBERG, T. R. (1956) Modern Archives: Principles and Techniques. Chicago: University of Chicago Press; SCHELLENBERG, T. R. (1965) The Management of Archives. New York: Columbia University Press.

5. JIMERSON, R.C. (2006) Embracing the Power of Archives. American Archivist. Vol. 69, № 1, P. 19-22; JIMERSON, R.C. (2007) Archives for All: Professional Responsibility and Social Justice. American Archivist. Vol. 70, № 2, P. 252-281.

6. COX, R.J. (2009) Secrecy, Archives, and the Archivist: A Review Essay (Sort Of). American Archivist. Vol. 72, № 1, P. 214-231.

7. COOK, T., SCHWARTZ, J.M. (2002) Archives, Records, and Power: The Making of Modern Memory. Archival Science. Kluwer Academic Publishers, № 2, P. 1-19.

8. CARTER, R. (2006) Of Things Said and Unsaid: Power, Archival Silences, and Power in Silence. Archivaria. Vol. 61, P. 215-233.

9. EASTWOOD, T. (2002) Reflections on the Goal of Archival Appraisal in Democratic Societies. Archivaria. Vol. 54, P. 59-71.

10. HARRIS, V. (2007) Archives and Justice: A South African Perspective. Chicago: Society of American Archivists.

11. KETELAAR, E. (2002) Archival Temples, Archival Prisons: Modes of Power and Protection. Archival Science. Kluwer Academic Publishers. № 2, P. 221-238.

12. PROCTER, M., COOK, M. and WILliAMS, C. (eds.) (2005) Political Pressure and the Archival Record. Chicago: Society of American Archivists.

13. WARNER, R. (1995) Diary of a Dream: A History of the National Archives Independence Movement, 1980-1985. Metuchen, NJ. and London: The Scarecrow Press; WARNER, R. (1992) International Archival Adventures: A Reminiscence. American Archivist. Vol. 55, № 2, P. 356-368.

14. BLOUIN, F. (2007) The Two Dimensions of Professional Service: A Reflection on the Life of Robert M. Warner. American Archivist. Vol. 70. № 2. P.401-409; BLOUIN, F. Remembering Robert M. Warner (2013) [Online] Available from: http://bentley.umich.edu/general/warner.php (Accessed: April 4, 2013)

15. WILSON, I.E. (1998) Diary of a Dream: A History of the National Archives Independence Movement, 1980-1985. Reviews. American Archivist. Vol. 62. № 1, P. 164-197.

16. FRIEDMAN L., NEAL, K. (1994), MONAHAN, Z. (2005). Finding aid for Robert M. Warner Papers, 1958-1992. University Archives and Records Program Bentley Historical Library University of Michigan. [Online] Available from: http://quod.lib.umich.edu/b/bhlead/umich-bhl89405?rgn=main;view=text (Accessed: August4, 2017); BLOUIN, F. (2013) Remembering Robert M. Warner [Online] Available from: http://bentley.umich.edu/general/warner.php (Accessed: April 4,2013)

17. BLOUIN, F.Jr., BELLARDO, L. Robert Warner. American Historical Association [Online] Available from: http://www.historians.org/perspectives/issues/2007/0709/0709mem3.cfm (Accessed: August 4,2017)

18. BLOUIN, F. (2007) The Two Dimensions of Professional Service: A Reflection on the Life of Robert M. Warner. American Archivist. Vol. 70, № 2, P. 401-409.

19.BULAT, P. (2015). Lyvanskaya vojna 1982 h. - «Myr Halylee». Ystoryya odnoho myfa. Chast" IV. Shest" dnej [Online] Available from: 
https://www.researchgate.net/publication/279961015_Ob_istorii_odnogo_mifa_Cast_IV_Sest_dnej (Accessed: August 4,2017); Lyvanskaya vojna. Elektronnaya evrejskaya Encyklopedyya. [Online] Available from: http://www.eleven.co.il/article/12442 (Accessed: August 4, 2017); Voennaya pomoshh" SSSR stranam Blyzhneho y Sredneho Vostoka. Uchastye kontynhenta sovetskyx vojsk v arabo-yzrayl"skyx vojnax (1956-1982 hh.). Rossyya (SSSR) v vojnax vtoroj polovyny XX veka (2002). Moskwa: TryadaFarm. P. 447-482; POBORCEV, A. (2009). Bejrut-82: Neyzvestnaya vojna Brezhneva. FILM. (DVD). [Online] Available from: https://rutube.ru/video/bbf607bf3fe2b535ba964lecaaebe4a9 (Accessed: August 4, 2017)

20. MARTIN, G. (2005) The Routledge Atlas of the Arab-Israeli Conflict. $8^{\text {th }}$ Edition with thirtytwo new maps. London and New York, 2005.

21. Central State Archives of Supreme Bodies of Power and Government of Ukraine. [Fond 14, inv. 2, file 3122, page 128].

22. MITYUKOV, O. (1983) XXI Mizhnarodna konferenciya Kruhloho Stola Arxiviv. Arxivy Ukrayiny. Naukovo-informacijnyj byuleten" Holovnoho arxivnoho upravlinnya pry Radi Ministriv Ukrayins"koyi RSR, 2 (178), P. 17-24.

23. In Memoriam: Paul Alsberg. International Council on Archives (2004) [Online] Available from: http://www.wien2004.ica.org/en/node/813 (Accessed: April 4, 2013); ALOUFI, Z. (2008) Apprisal at the Municipal Archives in Israel. Atlanti. Vol. 18, P. 287-295; ALSBERG, A. (ed.) (1973) Guide to the archives in Israel. Jerusalem : Israel Archives Association.; ALSBERG, P. (1975) The Israel State Archives as a source for the history of Palestine during the period of Ottoman rule. Studies on Palestine during the Ottoman Period. Jerusalem: Magnes Press; ALSBERG, P. (1978) The Israel State Archives. Archivaria. № 7, P. 70-75; ALSBERG, P. (1991) The Israel State Archives. Guides to the archives in Israel. Vol. 1. Jerusalem: Israel Archives Association.

24. HOOKER, V. and OTHMAN, N. (eds) (2003) Malaysia. Islam, Society and Politics. Singapore: Institute of Southeast Asian Studies; UFEN, A. (2009) Malaysia. Mobilizing Political Islam: Indonesia and Malaysia Compared. Commonwealth and Comparative Politics. Vol. 47, № 3, P. 308-333.

25. Datuk Zakiah Hanum Haji Abdul Hamid. Former ANM Director. National Archives of Malaysia [Online] Available from: http://www.arkib.gov.my/en/datuk-zakiah-hanum-haji-abdul-hamid (Accessed: April 4, 2013); ABISHEGAN, J. (1993) Datuk Zakiah Hanum. Sunday Style. New Sunday Times. P.5.

26. WARNER, R. (1992) International Archival Adventures: A Reminiscence. American Archivist. Vol. 55, № 2, P. 362.

27. WARNER, R. (1992) International Archival Adventures: A Reminiscence. American Archivist. Vol. 55, № 2, P. 357-360; MITYUKOV, O. H. (1980) IX Mizhnarodna konferenciya kruhloho stolu arxiviv. Arxivy Ukrayiny. Naukovo-informacijnyj byuleten" Holovnoho arxivnoho upravlinnya pry Radi Ministriv Ukrayins"koyi RSR, 6 (164), P. 10-11.

28. WARNER, R. (1992) International Archival Adventures: A Reminiscence. American Archivist. Vol. 55, № 2, P. 361-362.

29. KRAUSKOPF, R. (1958) The Hoover Commissions and Federal Recordkeeping. American Archivist. Vol. 21, № 4, P. 371-385; ANGEL, H. (1953) Federal Records Management Since the Hoover Commission Report. American Archivist. Vol. 16, № 1, P. 13-26.

30. BYERS, J. Certification in America: The ACA Example. Academy of Certified Archivists (2017) [Online] Available from: https://www.certifiedarchivists.org/about-us/historicalresources/certification-in-america-the-aca-example (Accessed: August 4, 2017).

31. BRADSHER, G. (2009) Longest-Serving Archivist Wayne Grover Steered Agency during Critical Years. Prologue. Vol.41, № 4 [Online] Available from: http://www.archives.gov/publications/prologue/2009/winter/grover.html (Accessed: August 4, 2017).

32. WARNER, R. (1995) Diary of a Dream: A History of the National Archives Independence Movement, 1980-1985. Metuchen, NJ. and London: The Scarecrow Press, 1995. P. 102.

33. WARNER, R. (2005) Secrecy and Salesmanship in the Struggle for NARA's Independence. Proloque. Vol.37, № 1 [Online] Available from: http://www.archives.gov/publications/prologue/2005/spring/archivist-warner.html [Accessed: August 2017]; Archives Becomes Independent (1984) Abbey Newsletter. Vol. 8, № 6 [Online] Available from: http://cool.conservation-us.org/byorg/abbey/an/an08/an08-6/an08-602.html (Accessed: August 4, 2017). 
34. International Council on Archives (ICA) was created during an organizational conference on the $9^{\text {th }}$ of June, 1948 in Paris. Charles Samaran (1879-1982), the General Director of the Archives of France, was elected as the first President of the ICA. The Second Archivist of the United States Solon J. Buck (1884-1962 and the world renowned British archivist and scholar, Deputy Keeper of the Public Records Sir. Hilary Jenkinson (1882-1961) were elected as vice-presidents of the ICA. The First International Congress on Archives was held in Paris on 21-26 August 1950. U.S. Archivist Solon J. Buck came up with the initiative of creating ICA. // HOLMES, O. (1976) Toward an International Archives Program and Council, 1945-1950. American Archivist. Vol. 39, № 3, P. 287-296; BUCK, S. (1947) The Archivist's «One World». Presidential address, delivered at the tenth annual meeting of the Society of American Archivists, at Washington, October 24, 1946. American Archivists. Vol. 10, № 1. P. 9-24; NORTON, M. (1951) The First International Congress of Archivists, Paris, France August 2126, 1950. American Archivist. Vol. 14, № 1, P. 13-32.

35. WARNER, R. (1992) International Archival Adventures: A Reminiscence. American Archivist. Vol. 55, № 2. P. 363.

36. WARNER, R. (1992) International Archival Adventures: A Reminiscence. American Archivist. Vol. 55, № 2. P. 356-368; Sovetskye arxyvysty v SShA (1987). Sovetskye arxyvy. Nauchnoteoretycheskyj y nauchno-praktycheskyj zhurnal. M.: Hlavnoe arxyvnoe upravlenye pry Sovete Mynystrov SSSR, 3, p. 91-92; Arxyvysty yz SShA v SSSR (1988). Sovetskye arxyvy. Nauchnoteoretycheskyj y nauchno-praktycheskyj zhurnal. M.: Hlavnoe arxyvnoe upravlenye pry Sovete Mynystrov SSSR, 1, p. 104-105.

37. International Council on Archives and UNESCO Meetings, September and November, 1986 (1987) American Archivist. Vol. 50, № 2. P. 262-264.

38. SHELLEY, F. (1949) The Interest of J.Franklin Jameson in the National Archives: 1908-1934. American Archivist. Vol. 12, № 2. P. 129.

39. CONNOR, R. (1943) Adventures of an amateur archivist. American Archivist. Vol. 6. № 1. P. 7.

Надійшла до редколегії 05.05.2017

Лариса Левченко, доктор історичних наук, Чорноморський національний університет імені Петра Могили, м. Миколаїв

\section{РОБЕРТ ВОРНЕР І ЙОГО БОРОТЬБА ЗА НЕЗАЛЕЖНІСТЬ АРХІВІВ}

Анотація. Стаття висвітлюе біографію видатного американського архівіста Роберта Марка Ворнера та його зусилля, спрямованні на втілення до життя ідеї «архіви поза політикою». Р. М. Ворнер, перебуваючи на посаді 6-го Архівіста США (1980-1985), справив значний внесок у боротьбу за повернення Національному архіву США статусу «незалежної агениїі, наданого під час заснування архіву за законодавством 1934 р. Завдяки організаторським зусиллям Р. М. Ворнера, 1984 р. американські архівісти позбавилися впливу політизованого органу Адміністрачї служб загального призначення й змогли зосередитися на реалізації суто професійних функиій, спрямованих на поповнення архіву документами з історії американської наџії, видавничій діяльності, міжнародному співробітництві тощя. На міжнародній арені Р. М. Ворнер захищав ідею «архіви поза політикою» під час ХХI Міжнародної конференції круглого столу архівів (Куала-Лумпур, Малайзія), що відбувалася в складних міжнародних умовах Ліванської війни (1982). Захищаючи права представника Держави Ізраїль на участь у конферениіі, Р. М. Ворнер довів, щзо Міжнародна рада архівів є професійною організачією архівістів усього світу й вона не може піддаватися політичному впливові. Р. М. Ворнер був відомим у СРСР, оскільки розвивав співробітництво з радянськими архівістами, незважаючи на "холодну війну», й кілька разів відвідав Радянський Союз. В історії Національного архіву США P. М. Ворнер залишився найбільш шанованим керівником: 2005 року на день святкування 20-ї річниці незалежності Національного архіву США там було відкрито дослідницький центр на його честь. Автор статті також приділила увагу ключовим постатям описуваних подій - архівістам Ізраїлю, Радянського Союзу та Малайзії.

Ключові слова: Роберт Ворнер, США, Архівіст, Національний архів США. 